\title{
The activity of rosoxacin, fosfomycin, cefotiam, and spectinomycin on $\beta$-lactamase producing Neisseria gonorrhoeae
}

\author{
NORBERT DICKGIESSER AND PETER KUNTZ \\ From the Department of Medical Microbiology and Hygiene, University of Heidelberg, Mannheim, FRG
}

SUMMARY We measured the activity of rosoxacin, fosfomycin, cefotiam, and spectinomycin against 51 isolates of $\beta$-lactamase producing Neisseria gonorrhoeae, all of which were susceptible to each drug at sufficient concentrations. The development of strains of penicillinase producing $N$ gonorrhoeae (PPNG) which are resistant to spectinomycin can therefore be avoided, as there are alternative drugs.

\section{Introduction}

Penicillinase ( $\beta$-lactamase) producing Neisseria gonorrhoeae (PPNG) was first isolated in Liverpool in 1976, ${ }^{1}$ and these strains have since been isolated in many other countries of Europe, America, Asia, and Australia. A report from the Centers for Disease Control stated that worldwide in 1981 and 1982 there had been a twofold to sixfold increase in PPNG strains. ${ }^{2}$ These strains are clinically important as they are resistant to penicillin $G$, the most widely used treatment for gonorrhoea. The susceptibility of PPNG strains to several cephalosporins has been examined, and they have been shown to be sensitive, for example, to cefuroxime and cefoxitin. ${ }^{3}$ Nevertheless, in many countries the drug of choice for infections with PPNG strains is spectinomycin hydrochloride. As there may be a one step mutation of $\mathbf{N}$ gonorrhoeae to spectinomycin resistance, ${ }^{4}$ it is of growing concern that spectinomycin has been used more frequently in the past years for the treatment of gonorrhoea. To prevent this resistance, spectinomycin should be used only in special cases, and not as frequently as at present.

The purpose of this study was to examine alternative drugs to spectinomycin for the treatment of infections caused by PPNG strains. We tested the sensitivity to spectionomycin, cefotiam, fosfomycin, and rosoxacin of 51 PPNG strains isolated from different geographical areas.

Address for reprints: Priv Doz Dr med N Dickgiesser, Institut für Hygiene und Medizinische Mikrobiologie, Klinikum der Stadt Mannheim, Fakultaet für Klin Medizin der Universitaet Heidelberg, Postfach 23, 6800 Mannheim, FRG

Accepted for publication 3 November 1983

\section{Materials and methods}

BACTERIAL STRAINS

The 51 PPNG isolates examined came from: England (37), Nigeria (3), Hong Kong (1), Saudi Arabia (2), Cameroon (1), South Korea (1), Philippines (2), and Thailand (4). Deoxyribonucleic acid (DNA) isolation and agarose gel electrophoresis showed that 10 strains carried a 3.2 megadalton (Mdal) $\beta$-lactamase inducing plasmid and 41 strains carried a $4.6 \mathrm{Mdal}$ plasmid. Using isoelectric focusing, the $\beta$-lactamase produced by all the isolates was shown to be TEM1.

\section{CULTURE MEDIA}

Chocolate agar containing 1\% haemoglobin (BBL) and vitox enrichment (Oxoid) was used for culture of $N$ gonorrhoeae. Twofold dilutions of the following antibiotics were prepared for agar dilution testing: spectinomycin $2-128 \mathrm{mg} / \mathrm{l}$, cefotiam $0.015-16 \mathrm{mg} / \mathrm{l}$, fosfomycin 1-64 mg/l, and rosoxacin 0.007-2 mg/l.

TESTING SUSCEPTIBILITY TO ANTIBIOTICS

To prevent loss of the plasmid, the isolates were grown on chocolate agar containing $1 \mathrm{mg} / \mathrm{l}$ ampicillin. Overnight cultures were suspended in prewarmed GC broth ${ }^{5}$ to a $0.5 \mathrm{McFarland}$ standard $\left(10^{8}\right.$ colony forming units $\left.(\mathrm{cfu}) / \mathrm{ml}\right)$ and diluted to suspensions of $10^{7}$ and $10^{6} \mathrm{cfu} / \mathrm{ml}$. Using a multipoint inoculator, spots of $10^{5}, 10^{4}$, or $10^{3} \mathrm{cfu}$ were inoculated on to prewarmed chocolate agar containing the above antibiotics. The strains were incubated at $37^{\circ} \mathrm{C}$ in a $10 \%$ carbon dioxide incubator for $\mathbf{4 5}$ hours. The minimum inhibitory concentration (MIC) was the lowest concentration of a drug which inhibited growth completely. A 45 hour incubation 
period was chosen as it gave more reproducible results than the usual 20 hours. MICs of rosoxacin, fosfomycin, and spectinomycin were the same after 45 hours as after 20 hours, while that of cefotiam was one dilution higher after 45 hours than after 20 hours.

\section{Results}

The figure shows cumulative data on the susceptibilities of PPNG strains to rosoxacin, cefotiam, fosfomycin, and spectinomycin, with the MIC of rosoxacin being the lowest. The table shows the ranges of MICs related to inoculum sizes.

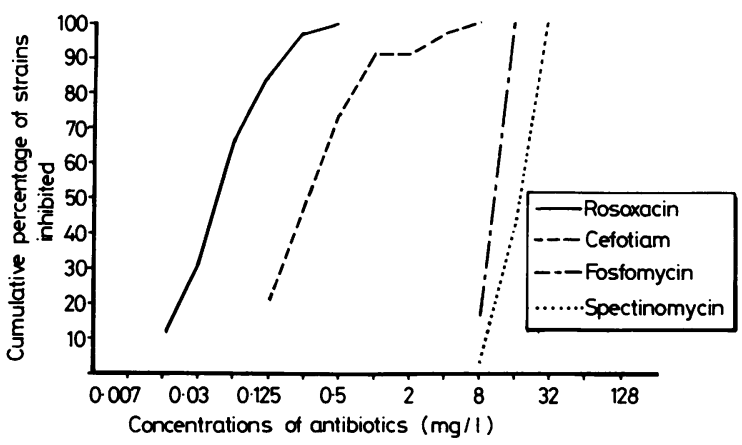

FIGURE Antibiotic susceptibilities of 51 PPNG strains using $10^{5} \mathrm{cfu} /$ inoculum

\section{Discussion}

Our data corresponded with susceptibility figures already published. MICs of fosfomycin of 8-32 mg/1 for non-PPNG strains have been reported, ${ }^{6}$ but there are no data for PPNG strains. The reported MICs of cefotiam $^{7}$ vary from 0.007 to $0.5 \mathrm{mg} / 1$ (PPNG strains) and 0.12 to $0.5 \mathrm{mg} / \mathrm{l}$ (non-PPNG strains); those in our study ranged from 0.03 to $8 \mathrm{mg} / \mathrm{l}$ depending on inoculum size. Reported MICs of rosoxacin vary from 0.007 to $0.06 \mathrm{mg} / \mathrm{l}$ (PPNG

TABLE Minimum inhibitory concentrations $(\mathrm{mg} / \mathrm{l})$ of four antibiotics to 51 PPNG strains tested on chocolate agar using three inoculum sizes

\begin{tabular}{llll}
\hline \multirow{4}{*}{ Inoculum sizes } \\
\cline { 2 - 4 } \cline { 2 - 3 } $10^{3} c f u / s p o t$ & $10^{4} c f u / s p o t$ & $10^{5} c f u / s p o t$ \\
\hline Rosoxacin & $0 \cdot 015-0 \cdot 5$ & $0 \cdot 015-0 \cdot 5$ & $0 \cdot 015-0 \cdot 5$ \\
Cefotiam & $0 \cdot 03-4$ & $0 \cdot 06-8$ & $0 \cdot 125-8$ \\
Fosfomycin & $8-16$ & $8-16$ & $8-16$ \\
Spectinomycin & $8-32$ & $8-32$ & $8-32$ \\
\hline
\end{tabular}

strains) and 0.007 to $0.5 \mathrm{mg} / 1$ (non-PPNG strains) $;^{8}$ those for our isolates were 0.015 to $0.5 \mathrm{mg} / \mathrm{l}$. Resistance to spectinomycin of 4-16 mg/l (PPNG strains) and $0 \cdot 5-31 \mathrm{mg} / 1$ (non-PPNG strains) has been reported; ${ }^{8}$ our results showed MICs of 8-32 $\mathrm{mg} / \mathrm{l}$.

Bacteria inhibited by concentrations of $<16 \mathrm{mg} / \mathrm{l}$ fosfomycin were considered to be susceptible, and strains inhibited by concentrations of $>64 \mathrm{mg} / \mathrm{l}$ were interpreted as being resistant. ${ }^{8}$ The half life of fosfomycin is $2 \frac{1}{2}$ hours, and serum concentrations after administration of $5 \mathrm{~g}$ are between $157 \mathrm{mg} / \mathrm{l}$ after one hour and $39 \mathrm{mg} / 1$ after six hours. ${ }^{10}$ Acute gonorrhoeal infections have been cured successfully using a single dose of $4 \mathrm{~g}$ fosfomycin. ${ }^{11}$ The half life of cefotiam is $\mathbf{4 5}$ minutes, and serum concentrations after a single dose of $1 \mathrm{~g}$ are between $30 \mathrm{mg} / \mathrm{l}$ after 30 minutes and $0.7 \mathrm{mg} / \mathrm{l}$ after five hours. Strains inhibited by concentrations of $\leqslant 8 \mathrm{mg} / \mathrm{l}$ cefotiam are considered to be susceptible, and those inhibited by concentrations of $>32 \mathrm{mg} / \mathrm{l}$ to be resistant, according to data given by the manufacturer. The half life of rosoxacin is $3 \cdot 4$ hours, and peak serum concentrations are between 4.6 and $4.9 \mathrm{mg} / 1 .{ }^{13}$ If it is administered orally as a single dose of $300 \mathrm{mg}$, serum concentrations are between $4.9 \mathrm{mg} / \mathrm{l}$ after two hours and $0.5 \mathrm{mg} / \mathrm{l}$ after 15 hours. ${ }^{13}$ Calubiran reported $100 \%$ cure rates of uncomplicated gonorrhoea using a single dose of $300 \mathrm{mg}$ rosoxacin. ${ }^{14}$ Strains of $N$ gonorrhoeae inhibited by $\leqslant 32 \mathrm{mg} / \mathrm{l}$ spectinomycin are interpreted as being sensitive. ${ }^{8} 15$ We concluded, therefore, that the PPNG strains tested were susceptible to fosfomycine, cefotiam, rosoxacin, and spectinomycin provided there is sufficient diffusion of the drugs.

This report shows the possibility of treating infections caused by PPNG strains with rosoxacin, cefotiam, fosfomycin, or spectinomycin. An advantage of treatment with rosoxacin is that it can be administered orally. The development of mutant strains resistant to spectinomycin can therefore be avoided, as alternative drugs are available.

\section{References}

1. Percival A, Rowlands J, Corkill JE, et al. Penicillinase producing gonococci in Liverpool. Lancet 1976; ii: 1379-82.

2. Centers for Disease Control. MMWR 1982;31:1

3. Phillips I, Shannon K. The activity of cephalosporins on $\beta$-lactamase-producing Neisseria gonorrhoeae. Scand J Infect Dis Suppl 1978; 13:23-6.

4. Ashford WA, Potts DW, Adams HJU, et al. Spectinomycinresistant penicillinase-producing Neisseria gonorrhoeae. Lancet 1981; ii: $1035-7$.

5. Sparling PF. Genetic transformation of Neisseria gonorrhoeae to streptomycin resistance. J Bacteriol 1966; 92:1364-71.

6. Vomel W, Abshagen U, Betzien G, Haag R, Hoffman R. Zur Humanpharmakokinetik und antibakteriellen in-vitro Aktivităt von Fosfomycin. Der Krankenhausarzt 1981;54:771-9. 
7. Braveny I, Machka K. Activity of cefotiam (CGP 14 112/E) against Haemophilus influenzae, Neisseria gonorrhoeae, and Neisseria meningitidis, including $\beta$-lactamase-producing isolates, in vitro. In: Nelson JD, Grassi C, eds. Current chemotherapy and infectious disease. Proceedings of the 11th International Congress of Chemotherapy and the 19th Interscience Conference on Antimicrobial Agents and Chemotherapy 1979. Washington DC: American Society for Microbiology 1980: 225-7.

8. Braveny I, Machka K. In vitro Aktivităt von Rosoxacin (Win 35213) gegen Neisseria gonorrhoeae. Arzneim Forsch 1980; 30: 1476-8.

9. Vömel W. Bakteriologische Fragen zu Fosfomycin. In: Fosfomycin - ein neuartiges Antibiotikum. Frankfurt and Zürich: Pharmaceutical and Medical Information Verlags GmbH 1982.

10. Sinagowitz E, Klemm W, Langmaack H, Daschner F. Gewebekonzentrationen von Fosfomycin beim Menschen. Klinikarzt 1981; 10:429-4.
11. Lopez-Gracia J. Treatment of acute and subacute gonococcal urethritis with fosfomycin. Chemotherapy 1977;23 suppl 1: 293-300.

12. Sakai T, Agishi Y, Yamaguchi N. Phase I studies on cefotiam (SCE-963) administered intravenously. Translated from: Chemotherapy (Tokyo) 1979; 27: 181-91.

13. Park GB, Saneski J, Weng T, Edelson J. Pharmacokinetics of rosoxacin in human volunteers. J Pharm Sci 1982;71:461-2.

14. Calubiran OV, Crisologo-Vizconde LB, Tupasi TE, Torre CA, Limson BM. Treatment of uncomplicated gonorrhoea in women. Br J Vener Dis 1982; 58:231-5.

15. Rodriguez J, Fuxench-Chiesa Z, Ramirez-Ronda $\mathrm{CH}$, Kouri $\mathrm{Y}$ Cuevas R, Nevárez M, Pérez M. In vitro susceptibility of 50 non $\beta$-lactamase-producing Neisseria gonorrhoeae strains to 12 antimicrobial agents. Antimicrob Agents Chemother 1983; 23:242-4. 